\title{
Intertemporal Efficiency Analysis of Indonesian Sharia Commercial Bank after Spin off Period 2013-2017: Data Envelopment Analysis (Window Analysis)
}

\section{Ulfi Alayya ${ }^{1}$ and Lina Nugraha Rani²}

${ }^{1}$ Student of Bachelor Degree Islamic Economy Program - Business and Economy Faculty, Airlangga University

${ }^{2}$ Islamic Economy Department- Business and Economy Faculty, Airlangga University

\section{Abstract}

This study compares the operational stability of the Islamic Bank in Indonesia in post with a spin off research period 2013 to 2017 with the method of analysis with Window DEA or Intertemporal Efficiency Analysis. Window analysis is one of the development of DEA models that can measure the level of efficiency from time to time (intertemporal)

Corresponding Author: Ulfi Alayya upiy10112@gmail.com

Received: 10 February 2019 Accepted: 14 March 2019 Published: 28 March 2019

Publishing services provided by Knowledge E

(c) Ulfi Alayya and Lina Nugraha Rani. This article is distributed under the terms of the Commons Attribution License, which permits unrestricted use and redistribution provided that the original author and source are credited.

Selection and Peer-review under the responsibility of the ICIEBP Conference Committee.

\section{Introduction}

The beginning of Islamic banks development in Indonesia since the establishment of Indonesian Muamalat Bank (IMB) and the permission of Conventional Banks to have UUS, it was first carried out by Mandiri Sharia Bank in 1999, which was a conversion of Susila Bakti Bank. Susila Bakti Bank is a conventional bank that was purchased by Nation Trade Bank, which was later converted into Mandiri Sharia Bank, it can be said to be the second Islamic bank in Indonesia. From 2007 to 2017, the number of Sharia Commercial Banks increased from 3 BUS to 13 BUS. The development of Islamic banks is supported by the occurrence of spin offs conducted by several banks.

Spin Off or separation is defined in Article 1 Number 12, Article 135 of Law Number 40 of 2007 concerning Limited Liability Company as a legal act carried out by the 
Company to separate the business which results in the entire assets and liabilities of the Company switching due to the law of 2 (two) companies or more or half of the assets and liabilities of the Company switching due to law to 1 (one) Company or more. Based on this definition, it can be understood that what is meant by Spin Off is the process of separating UUS from its parent bank into an Sharia Commercial Bank with its own independent legal entity (Rasyid, 2016).

On the other hand, the increasing existence of Islamic banking must be balanced with the objectives of the bank. One of the main objectives is efficiency. If the financial institution in its business activities is not efficient, it will result in an inability to compete in collecting and distributing funds. The more efficient a financial institution is, the easier it is to obtain the optimal level of profit (Adikara, 2014).

The rest of the efficiency concept in Islamic economics is reflected in the word of God in the letter Al-Israa verses 26-27:

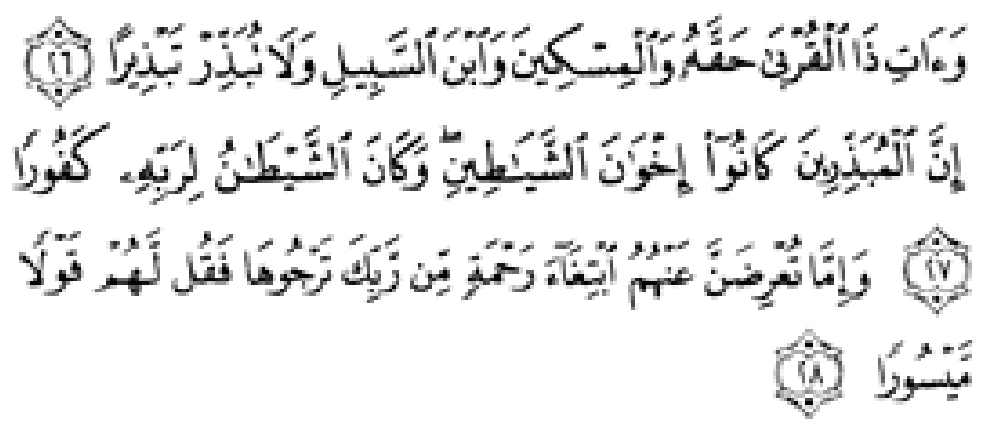

Wa āti żal-qurbā haqqahụ wal-miskīna wabnas-sabīli wa lā tubażżir tabżīrā. Innal-mubażżirīna kānū ikhwānasy-syayātīn, wa kānasy-syaitānu lirabbihī kafưrā

Meaning: "And give to the families who are close to their rights, to the poor and those who are on the journey and do not use (your wealth) wastefully. In fact, the spenders are the brothers of Satan and the Satan itself is very apostatize to his Lord. "(Surat al-Israa: 26-27)

Tabdzir word (waste) is interpreted as expenditures that are not good. A spender is categorized as the demon's brother. (Shihab, 2002: 72-73). This means that humans use resources that must match their needs and not waste.

One of the most popular approaches to measure efficiency is Data Envelopment Analysis. Data Envelopment Analysis (DEA) was introduced by Charnes, Cooper, and Rhodes. This method is one of the evaluation tools to examine the performance of an activity in an entity unit. 
Flokou et al (2017) said that the assessment of the DEA analysis only tested the Decision Making Unit (DMU) measures related to other samples. This causes the efficiency comparison of the same set of units in two different or more different time periods cannot be analyzed. Therefore, an Intertemporal perspective can be applied to compare the value of efficiency over time (changes in efficiency) to the sample itself.

The need to use this window analysis method is to find out the intertemporal efficiency of the Islamic banking industry in Indonesia for this study. Charnes et al (1985) proposed a technique that is window analysis in DEA. Window analysis assesses the performance of a company within a certain period of time by treating it as a different entity in each period of time.

This study will see among the Sharia Commercial Banks regarding which ones that are the most stable in the level of bank efficiency in order to achieve good bank management. This study used the DEA Window Analysis method, a large number of samples consisting of 9 banks, with a period of 5 years. Input variables used in this study were variable labor costs and TPF, while the output variables were financing variables and operating income. In other words, this research is a development for the efficiency study of existing Islamic banks in Indonesia and could provide more comprehensive and deeper results.

\section{Literature Review}

\subsection{Spin off}

Separation or spin off is a legal action that aims to separate themselves which occurred before in a legal entity, then it "splits" with legal recognition of its division. (Nasuha, 2012)

\subsection{Sharia bank efficiency}

From an Islamic economy point of view, the concept of efficiency is in line with sharia principles that aim to achieve and maintain the sharia maqashid (Kamaruddin et al. 2008: 33). Islam strongly advocates efficiency in all human activities while on earth. One of them is that humans are advised to not to be wasteful in any case including when using their possessions. 


\subsection{Data envelopment analysis (DEA)}

Data Envelopment Analysis (DEA) is a mathematical programming technique that is used to evaluate a relative efficiency collection of decision-making units in managing resources with the same type, so that they become the same output where the relationship of function forms from input to output is unknown (Coelli, 1996)

Data Envelopment Analysis (DEA) was first introduced by Charnes, Copper, and Rhodes in 1978. DEA is a linear program application technique that measures the relative efficiency of each production unit compared to other production units that have the same goal. The production unit in the DEA is called a Decision Making Unit (DMU) or the unit that is tested, which can be in the form of a bank, manager, or anything that wants to be evaluated. The efficiency score generated by Data Envelopment Analysis (DEA) ranges from 0 - 1 . If a DMU has a value less than 1 then it is considered a unit that is relatively inefficient compared to the other units.

\subsection{Window analysis}

DEA window analysis was introduced by Charnes et al. (1994). Window analysis is one of the development of DEA models that can measure the level of efficiency from time to time (intertemporal) observations on inputs and outputs from the DMU over several time periods, it is important to conduct panel data analysis where it focuses on changes in efficiency from time to time. Specifically, the DMU performance in a certain period is compared to the performance in the period other than the performance of other DMUs. Namely standard deviations (SD), Long Distance per Window (LDW), Long Distance per Period (LDP) and Long Distance per Year (LDY). These four measurements as recommended by Cooper et al (2011) can be used as an efficiency stability analysis achieved from each DMU.

Window analysis is based on the "window" or DMU group for a certain number of consecutive time periods. In this analysis, DMU is in the window for two different periods of $\mathrm{I}$ and $\mathrm{j}$ which are considered two different DMUs. Measurement of intertemporal efficiency in this study was analyzed using the DEA Window analysis with the following formula:

$$
W=K-P+1
$$

Description:

$\mathrm{W}=$ the window amount 
$\mathrm{K}=$ observation time period amount

$\mathrm{P}=$ the window length

\section{Research Methodology}

Based on the formulation of the research problem, the input variables in this study were labor costs and third party funds, and the output variables were total financing and bank operating income. The approach used in this study is a quantitative approach.

\subsection{Operational definition}

\subsubsection{Labor costs}

According to Mulyadi (2000) labor is a physical or mental effort issued by employees to process products. Labor costs are the prices charged for the use of human labor. In this case, the variable labor costs used for research are taken in the income statement of each sample bank.

\subsubsection{TPF}

Third Party Funds (TPF) according to PBI No. 17/11/ PBI/ 2015 is the Bank's liability for residents and non-residents in Rupiah and foreign currencies. Deposits used are taken from the financial summary report contained in each bank's annual financial statement.

\subsubsection{Total costs}

Financing according to PBI No. 15/16/PBI/2013 is bank assets in the form of mudharabah financing, musharaka financing, receivables and ijarah financing. The financing used is taken from the financial summary report contained in each bank's annual financial statement.

\subsection{Operational income}

To understand income according to PSAK Number 223 (IAI 2002, paragraph 6), income is the gross inflow of economic benefits arising from the normal activities of a company during a period if the inflow results in an increase, which does not originate from the 
contribution of the capital role. The meaning of operational income is income generated from the main, routine and sustainable activities by the company. Operating income used is taken from the financial summary report contained in each bank's annual financial statements.

\subsection{Data source and type}

This study used secondary data derived from the Annual Report of each sample bank and which was found on the official website of each bank. According to Sugiyono (2005: 62), secondary data is data that does not directly provided to the researchers, for example, research must go through other people or search through documents. Secondary data was obtained by conducting literature studies on previous books and research.

\subsection{Population dan sample}

The sample collection used in this study was purposive sampling technique. Regarding this, Sugiyono (2010: 85) stated that purposive sampling is a sample determination technique with certain considerations. This means that every subject taken from the population is chosen deliberately based on certain goals and considerations. The sample criteria used in this study are as below:

1. Sharia Commercial Bank after spin off in Indonesia, which is registered with the Financial Services Authority and has been operating in the study period is during the post spin off period 2013-2017

2. Sharia Commercial Banks in Indonesia which have complete annual financial statements published on the official website of each bank and published through the OJK website during the post spin off period 2013-2017

The category of Sharia Commercial Banks post spin off referred to the category is Sharia Commercial Banks that have separated assets from their parent banks in 2013 so that the financial statements for the 2013-2017 period can be taken. Based on the above criteria, the banks that meet the criteria are 9 banks. The following is a list of Sharia Commercial Banks used as research samples: 
TABLE 1: List of Sharia Commercial Banks which fulfilled the research sample criteria.

\begin{tabular}{|l|l|c|}
\hline No & Bank Names & Spin-Off Year \\
\hline 1. & Bukopin Sharia Bank & 2009 \\
\hline 2. & BRI Sharia Bank & 2010 \\
\hline 3. & Panin Dubai Sharia Bank & 2010 \\
\hline 4. & BNI Sharia Bank & 2010 \\
\hline 5. & BCA Sharia Bank & 2010 \\
\hline 6. & Maybank Sharia Bank & 2010 \\
\hline 7. & Jabar Banten Sharia Bank & 2011 \\
\hline 8. & Victoria Sharia Bank & 2011 \\
\hline 9. & Sharia Mandiri Bank & 2013 \\
\hline
\end{tabular}

\subsection{Analysis technique}

The efficiency measurement of Indonesian sharia commercial banks after spin off in the 2013-2017 period in this study used the DEA window analysis method to determine the intertemporal efficiency of each DMU from time to time using the intermediation approach.

\subsection{Technical efficiency model}

\subsubsection{Model CRS output oriented}

$$
\begin{gathered}
\operatorname{Max}_{\Phi, \lambda} \Phi, \text { s.t }-\Phi y_{i}+Q \lambda \geq 0 \\
x_{i}-X \lambda \geq 0 \\
\lambda \geq 0
\end{gathered}
$$

where:

$$
\begin{aligned}
& \Phi=\text { efficiency score } \\
& \lambda=1 \times 1 \text { constant vector or obstacle vector } \\
& \mathrm{y}_{i}=\text { vector of } \mathrm{i} \text { output } \\
& \mathrm{x}_{i}=\text { vector } \mathrm{i} \text { input } \\
& \mathrm{Q}=\text { a whole ouput } \mathrm{i} \text { matrics } \\
& \mathrm{X}=\text { a whole input } \mathrm{i} \text { matrics }
\end{aligned}
$$




\subsubsection{Model VRS output oriented}

$$
\begin{gathered}
\operatorname{Max}_{\Phi, \lambda} \Phi \text {, s.t }-\Phi \mathrm{y}_{i}+\mathrm{Q} \lambda \geq 0 \\
\mathrm{x}_{i}-\mathrm{X} \lambda \geq 0 \\
\mid 1^{\prime} \lambda=1 \\
\lambda \geq 0
\end{gathered}
$$

where:

$$
\begin{aligned}
& \Phi=\text { efficiency score } \\
& \lambda=1 \times 1 \text { constant vector or obstacle vector } \\
& y_{i}=\text { vector of } i \text { output } \\
& x_{i}=\text { vector } i \text { input } \\
& Q=\text { a whole ouput i matrics } \\
& X=\text { a whole input i matrics }
\end{aligned}
$$

\subsubsection{Intertemporal efficiency}

This analysis produces the intertemporal efficiency value of each DMU every year, besides it is also able to generate the value of Long Distance per Window (LDW), Long Distance per Year (LDY), and Long Distance per all Period (LDP). LDW explains the biggest difference from the efficiency score in one window, then the LDP measures the biggest difference from the efficiency score in the entire observation period, then the explanation of the biggest difference from the efficiency score in one year is illustrated by LDY score (Rusydiana, 2013).

In DEA window analysis, the analysis is done using DEAP 2.1 software and then processed with Microsoft Excel software.

\section{Result and Discussion}

\subsection{Intertemporal average score of sharia commercial bank after spin off period 2013-2017}


TABLE 2: Intertemporal Efficiency Estimation Results CRS Assumptions.

\begin{tabular}{|c|c|c|c|c|c|c|c|c|c|c|c|}
\hline DM U & $\begin{array}{c}\text { Wind } \\
\text { ow }\end{array}$ & 2013 & 2014 & 2015 & 2016 & 2017 & $\begin{array}{c}M \text { ea } \\
\text { n/Wi } \\
\text { ndo } \\
\text { w }\end{array}$ & $\begin{array}{c}\text { M ea } \\
n\end{array}$ & $\begin{array}{l}\text { LD } \\
W\end{array}$ & $\begin{array}{c}\text { LD } \\
P\end{array}$ & $\begin{array}{c}\text { Ran } \\
k\end{array}$ \\
\hline \multirow{4}{*}{$\begin{array}{c}\text { BUKOPI } \\
\text { N } \\
\text { SYARI } \\
\text { AH }\end{array}$} & 1 & 1 & 1 & 1 & & & 1 & \multirow{4}{*}{0,987} & 0,00 & & \multirow{4}{*}{9} \\
\hline & 2 & & 1 & 1 & 0.981 & & 0,99 & & 0,019 & 0,077 & \\
\hline & 3 & & & 1 & 1 & 0.923 & 0,97 & & 0,077 & & \\
\hline & LDY & $x$ & 0,00 & 0,00 & 0,019 & $x$ & & & & & \\
\hline \multirow{4}{*}{$\begin{array}{c}\text { BRI } \\
\text { SYARI } \\
\text { AH }\end{array}$} & 1 & 1 & 1 & 1 & & & 1 & \multirow{4}{*}{1} & 0,00 & \multirow{4}{*}{0,00} & \multirow{4}{*}{1} \\
\hline & 2 & & 1 & 1 & 1 & & 1 & & 0,00 & & \\
\hline & 3 & & & 1 & 1 & 1 & 1 & & 0,00 & & \\
\hline & LDY & $x$ & 0,00 & 0,00 & 0,00 & $x$ & & & & & \\
\hline \multirow{4}{*}{$\begin{array}{c}\text { PANIN } \\
\text { DUBAI } \\
\text { SYARI } \\
\text { AH }\end{array}$} & 1 & 0.941 & 1 & 1 & & & 0,98 & \multirow{4}{*}{0,97} & 0,059 & & \multirow{4}{*}{2} \\
\hline & 2 & & 1 & 1 & 0.954 & & 0,98 & & 0,046 & 0,098 & \\
\hline & 3 & & & 1 & 0.954 & 0.902 & 0,95 & & 0,098 & & \\
\hline & LDY & $x$ & 0,00 & 0,00 & 0,00 & $x$ & & & & & \\
\hline \multirow{4}{*}{$\begin{array}{c}\text { BNI } \\
\text { SYARI } \\
\text { AH }\end{array}$} & 1 & 1 & 1 & 1 & & & 1 & \multirow{4}{*}{0,99} & 0,00 & & \multirow{4}{*}{3} \\
\hline & 2 & & 1 & 1 & 1 & & 1 & & 0,00 & 0,063 & \\
\hline & 3 & & & 1 & 0.937 & 1 & 0,98 & & 0,063 & & \\
\hline & LDY & $x$ & 0,00 & 0,00 & 0,063 & $x$ & & & & & \\
\hline \multirow{4}{*}{$\begin{array}{c}\text { BCA } \\
\text { SYARI } \\
\text { AH }\end{array}$} & 1 & 0.913 & 0.997 & 1 & & & 0,97 & \multirow{4}{*}{0,987} & 0,087 & & \multirow{4}{*}{4} \\
\hline & 2 & & 0.997 & 1 & 1 & & 0,99 & & 0,003 & $0,08 才$ & \\
\hline & 3 & & & 1 & 1 & 1 & 1 & & 0,00 & & \\
\hline & LDY & $x$ & 0,00 & 0,00 & 0,00 & $x$ & & & & & \\
\hline \multirow{4}{*}{$\begin{array}{c}\text { MAYB } \\
\text { ANK } \\
\text { SYARI } \\
\text { AH }\end{array}$} & 1 & 0,996 & 1 & 1 & & & 0,99 & \multirow{4}{*}{0,957} & 0,004 & & \multirow{4}{*}{5} \\
\hline & 2 & & 1 & 1 & 0,818 & & 0,94 & & 0,182 & 0,182 & \\
\hline & 3 & & & 1 & 0,818 & 1 & 0,94 & & 0,182 & & \\
\hline & LDY & $x$ & 0,00 & 0,00 & 0,00 & $x$ & & & & & \\
\hline \multirow{4}{*}{$\begin{array}{c}\text { BJB } \\
\text { SYARI } \\
\text { AH }\end{array}$} & 1 & 1 & 0.983 & 1 & & & 0,99 & \multirow{4}{*}{0,967} & 0,017 & & \multirow{4}{*}{7} \\
\hline & 2 & & 1 & 1 & 0.939 & & 0,98 & & 0,061 & 0,121 & \\
\hline & 3 & & & 1 & 0.939 & 0.879 & 0,93 & & 0,121 & & \\
\hline & LDY & $x$ & 0,017 & 0,00 & 0,00 & $x$ & & & & & \\
\hline \multirow{4}{*}{$\begin{array}{c}\text { M ANDI } \\
\text { RI } \\
\text { SYARI } \\
\text { AH }\end{array}$} & 1 & 1 & 0.963 & 0.996 & & & 0,99 & \multirow{4}{*}{0,99} & 0,037 & & \multirow{4}{*}{8} \\
\hline & 2 & & 0.999 & 1 & 1 & & 0,99 & & 0,00 & 0,037 & \\
\hline & 3 & & & 1 & 0.993 & 1 & 0,99 & & 0,007 & & \\
\hline & LDY & $x$ & 0,036 & 0,00 & 0,007 & $x$ & & & & & \\
\hline & 1 & 0,888 & 1 & 1 & & & 0,96 & & 0,112 & & \\
\hline $\begin{array}{l}\text { VICTO } \\
\text { RIA }\end{array}$ & 2 & & 1 & 1 & 1 & & 1 & 0,983 & 0,00 & 0,112 & 6 \\
\hline $\begin{array}{c}\text { SYARI } \\
\text { AH }\end{array}$ & 3 & & & 1 & 1 & 0.998 & 0,99 & & 0,002 & & \\
\hline & LDY & $x$ & 0,00 & 0,00 & 0,00 & $x$ & & & & & \\
\hline
\end{tabular}




\subsubsection{CRS model}

Based on the DEA window analysis in each DMU that has been carried out, it can be concluded that the average intertemporal efficiency of Sharia Commercial banks after spin off is $98 \%$. By using the CRS assumption, BRI sharia bank became the most stable bank within the Sharia Commercial Bank after spin off, the only one to achieve an intertemporal efficient condition. On the other hand, BRI sharia bank also have the most stable efficiency score in each year when compared to other Sharia Commercial Banks with the smallest LDP score of 0 , and also followed by Mandiri Sharia Bank with an LDP score of 0.037. Furthermore, BNI sharia bank ranked third which has a stable efficiency score with an LDP score of 0.063. Bukopin sharia bank also has a stable efficiency score with an LDP score of 0.077 , followed by BCA sharia bank with an LDP score of 0.087. Furthermore, Panin Dubai sharia bank obtained an LDP score of 0.098 . Victoria bank was ranked second from the end within the most stable efficiency score with an LDP score of 0.112. Whereas BJB sharia bank became the most unstable bank with an efficiency score and an LDP score of 0.121

\subsubsection{VRS model}

From the results of processed data outputs, the efficiency of Sharia Commercial Banks are calculated based on the variable return to scale. The average score of intertemporal efficiency calculated in VRS assumptions is 99\%. There are 6 banks that achieved intertemporal efficient conditions which are BRI sharia bank, BNI sharia bank, BCA sharia bank, Maybank sharia, Victoria sharia bank, Panin Dubai sharia bank. Those six banks are also stable with a small LDP score of 0 . Meanwhile, the BJB sharia bank is still the most inefficient Sharia CommercialBbank after spin off.

\section{Discussion}

Based on the results of data analysis, it is known that Islamic banking in Indonesia still operates inefficiently in the period of 2013-2017. This indicates that Islamic banking in Indonesia has not been able to maximize output, namely financing and operating income.

BRI sharia bank is the most efficient and stable out of the other several banks that is the research sample. This proves the concept of efficiency, which emphasizes the utilization of certain company inputs to achieve maximum output levels. In this case, 
BRI Sharia able to utilize inputs, namely TPF \& labor costs to produce maximum output, namely financing and operating income.

The fact that BRI sharia bank is the most efficient bank is also supported by the achievement of being ranked first in the "The Most Efficient Bank \& The Most Reliable Bank" category at the Indonesia Banking Award (IBA) 2017. Also supported by spin offs that have been carried out by BRI sharia bank in advance compared to other banks after Bukopin shariah bank. Based on spin off experience since 2010, this has made BRI sharia bank to be the most efficient and most stable bank within the Sharia Commercial Bank after the spin off of the 2013-2017 period.

Sharia Commercial Banks also require an innovation and diversification of Islamic banking products as well as servies that are up to date with the latest technology in order to increase financing and operating income. Product innovation and diversification is the launch of new services that are unique and different according to the targeted customer segment. In addition, improving managerial expertise must also be done so that the internal management of Islamic banking can as much as possible manage the operational and financial arrangements of Islamic banking.

TABLE 3: Intertemporal Efficiency Estimation Results VRS Assumptions. 


\begin{tabular}{|c|c|c|c|c|c|c|c|c|c|c|c|}
\hline DMU & Window & 2013 & 2014 & 2015 & 2016 & 2017 & Mean/Window & Mean & LDW & LDP & Rank \\
\hline \multirow{4}{*}{$\begin{array}{l}\text { BUKOPIN } \\
\text { SYARIAH }\end{array}$} & 1 & 1 & 1 & 1 & & & 1 & \multirow{4}{*}{0.99} & 0,00 & \multirow{4}{*}{0,056} & \multirow{4}{*}{9} \\
\hline & 2 & & 1 & 1 & 1 & & 1 & & 0,00 & & \\
\hline & 3 & & & 1 & 1 & 0,944 & 0.981 & & 0,056 & & \\
\hline & LDY & $\mathrm{x}$ & 0,00 & 0,00 & 0,00 & $\mathrm{x}$ & & & & & \\
\hline \multirow{4}{*}{$\begin{array}{c}\text { BRI } \\
\text { SYARIAH }\end{array}$} & 1 & 1 & 1 & 1 & & & 1 & \multirow{4}{*}{1} & 0,00 & \multirow{4}{*}{0,00} & \multirow{4}{*}{1} \\
\hline & 2 & & 1 & 1 & 1 & & 1 & & 0,00 & & \\
\hline & 3 & 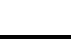 & & 1 & 1 & 1 & 1 & & 0,00 & & \\
\hline & LDY & $\mathrm{x}$ & 0,00 & 0,00 & 0,00 & $\mathrm{x}$ & & & & & \\
\hline \multirow[b]{2}{*}{$\begin{array}{l}\text { PANIN } \\
\text { DUBAI }\end{array}$} & 1 & 1 & 1 & 1 & & & 1 & \multirow{4}{*}{1} & 0,00 & \multirow{4}{*}{0,00} & \multirow{4}{*}{2} \\
\hline & 2 & & 1 & 1 & 1 & & 1 & & 0,00 & & \\
\hline \multirow[t]{2}{*}{ SYARIAH } & 3 & & & 1 & 1 & 1 & 1 & & 0,00 & & \\
\hline & LDY & $\mathrm{x}$ & 0,00 & 0,00 & 0,00 & $\mathrm{x}$ & & & & & \\
\hline \multirow{4}{*}{$\begin{array}{c}\text { BNI } \\
\text { SYARIAH }\end{array}$} & 1 & 1 & 1 & 1 & & & 1 & \multirow{4}{*}{1} & 0,00 & \multirow{4}{*}{0,00} & \multirow{4}{*}{3} \\
\hline & 2 & & 1 & 1 & 1 & & 1 & & 0,00 & & \\
\hline & 3 & & & 1 & 1 & 1 & 1 & & 0,00 & & \\
\hline & LDY & $\mathrm{x}$ & 0,00 & 0,00 & 0,00 & $\mathrm{x}$ & & & . & & \\
\hline \multirow{4}{*}{$\begin{array}{c}\text { BCA } \\
\text { SYARIAH }\end{array}$} & 1 & 1 & 1 & 1 & & & 1 & \multirow{4}{*}{1} & 0,00 & \multirow{4}{*}{0,00} & \multirow{4}{*}{4} \\
\hline & 2 & & 1 & 1 & 1 & & 1 & & 0,00 & & \\
\hline & 3 & & & 1 & 1 & 1 & 1 & & 0,00 & & \\
\hline & LDY & $\mathrm{x}$ & 0,00 & 0,00 & 0,00 & $\mathrm{x}$ & & & & & \\
\hline \multirow{4}{*}{ SYARIAH } & 1 & 1 & 1 & 1 & & & 1 & \multirow{4}{*}{1} & 0,00 & \multirow{4}{*}{0,00} & \\
\hline & 2 & & 1 & 1 & 1 & & 1 & & 0,00 & & \\
\hline & 3 & & & 1 & 1 & 1 & 1 & & 0,00 & & \\
\hline & LDY & $\mathrm{x}$ & 0,00 & 0,00 & 0,00 & $\mathrm{x}$ & & & & & 5 \\
\hline & 1 & 1 & 1 & 1 & & & 1 & & 0,00 & & \\
\hline $\begin{array}{c}\text { BJB } \\
\text { SYARIAH }\end{array}$ & 2 & & 1 & 1 & 1 & & 1 & 0,99 & 0,00 & 0,009 & 7 \\
\hline & 3 & & & 1 & 0,991 & 1 & 0,99 & & 0,009 & & \\
\hline & LDY & $\mathrm{x}$ & 0,00 & 0,00 & 0,009 & $\mathrm{x}$ & & & & & \\
\hline & 1 & 1 & 0,967 & 1 & & & 0,99 & & 0,033 & & \\
\hline MANDIRI & 2 & & 1 & 1 & 1 & & 1 & 0,99 & 0,00 & 0,033 & 8 \\
\hline SYARIAH & 3 & & & 1 & 0,994 & 1 & 0,99 & & 0,006 & & \\
\hline & LDY & $\mathrm{x}$ & 0,036 & 0,004 & 0,007 & $\mathrm{x}$ & & & & & \\
\hline & 1 & 1 & 1 & 1 & & & 1 & & 0,00 & & \\
\hline VICTORIA & 2 & & 1 & 1 & 1 & & 1 & 1 & 0,00 & 0,00 & 6 \\
\hline SYARIAH & 3 & & & 1 & 1 & 1 & 1 & & 0,00 & & \\
\hline & LDY & $\mathrm{x}$ & 0,00 & 0,00 & 0,00 & $\mathrm{x}$ & & & & & \\
\hline
\end{tabular}




\section{Conclusion and Suggestion}

Based on the background, formulation of the problem, and the discussion that has been described previously, the following conclusions can be drawn:

1. The average intertemporal efficiency score of Sharia commercial banks for the period 2013-2017 assuming CRS reached 98\% and under VRS assumptions reached 99\%, which means that the Sharia banks for the 2013-2017 period still operate inefficiently and potentially increase their output by $1-2 \%$ more to achieve efficient conditions.

2. Under the CRS assumption, BRI sharia bank became the most stable bank within the Sharia commercial bank after spin off, the only one achieving intertemporal efficient conditions in Sharia commercial banking in Indonesia. On the other hand, BRI sharia bank also has the most stable efficiency score every year when compared to other Sharia Commercial Banks with the smallest LDP score of 0.

3. While under VRS assumptions, there are 6 banks that achieved intertemporal efficient conditions in Sharia commercial banking in Indonesia which are BRI sharia bank, BNI sharia bank, BCA sharia bank, Maybank sharia, Victoria sharia bank, Panin Dubai sharia bank. Those six banks are also stable with a small LDP score of 0 . Meanwhile, BJB sharia bank is still the most inefficient Sharia Commercial Bank after spin off.

\section{Suggestion}

1. In the Interest of Sharia Commercial Bank

Sharia Commercial Banks should pay attention to the internal conditions of the bank to improve efficiency. Sharia commercial banks also require innovation and diversification of Islamic banking products as well as services that are up to date with the latest technology in order to increase financing and operating income.

2. In the Interest of the Further Researches

Suggestions for further research are to use input variables and other output variables and add more research periods to measure the efficiency of Sharia Commercial Banks, so that the further research is more in-depth. 


\section{References}

[1] Al- Qur'an dan Terjemahnya. Kemenag RI. 2011. Jakarta: Adhi Aksara Abadi Indonesia.

[2] Anisitus, Amanat. (1996). Pembahasan Undang-Undang Perseroan Terbatas dan Penerapan dalam Akta Notaris. Jakarta: Rajawali Press

[3] Antonio, Muhammad Syafi'i. 2001. Bank Syariah: Dari Teori ke Praktik. Jakarta: Gema Insani Press. Jakarta.

[4] Arifin, Zainul. 2009. Dasar Dasar Manajemen Bank Syariah. Jakarta: Pustaka Alvabet.

[5] Ascarya. 2007. Akad dan Produk Bank Syariah. Jakarta: PT. Raja Grafindo

[6] Awdeh, A. and El Moussawi, C., 2009. Bank Efficiency and Foreign Ownership in the Lebanese Banking Sector. Review of Middle East Economics and Finance, 5(2), pp.66-87.

[7] Begum, Sabrina. 2017. "Analisis Tingkat Efisiensi Perbankan Syariah Di Indonesia Tahun 2010 - 2014 Dengan Menggunakan Metode Data Envelopment Analysis." Skripsi. Universitas Airlangga

[8] Charnes et al., 1994, Data Envelopment Analysis: Theory, Methodology, and Application, Kluwer.

[9] Coelli, T. J., Rao, D. S. P., Donnell, C. J., \& Battese G. E. 2005. An Introduction to Efficiency and Productivity Analysis. Queensland: Springer Science \& Business Media.

[10] Cvetkoska, V. and Savić, G., 2017. Efficiency of Bank Branches: Empirical Evidence from a Two-Phase Research Approach. Economic research-Ekonomska istraživanja, 30(1), pp.318-333.

[11] Flokou, A., Aletras, V., \& Niakas, D. 2017. A Window-DEA Based Efficiency Evaluation of the Public Hospital Sector in Greece during the 5 Year Economic Crisis, (Online), (http://journals.plos.org, diakses pada 5 Mei 2018).

[12] Firdaus, Faza dan Nadratuzzaman Hosen. 2013. Efisiensi Bank Umum Syariah Menggunakan Pendekatan Two-Stage Data Envelopment Analysis. BEMP Volume 16 Nomor 2 Oktober 2013

[13] Hadad, dkk. 2003. Analisis Efisiensi Industri Perbankan Indonesia: Penggunaan Metode Nonparametrik Data Envelopment Analysis (DEA). Buletin Ekonomi dan Perbankan, 7, pp.1-28.

[14] Hidayat, Rahmat. Efisiensi Perbankan Syariah: Teori Dan Praktek. Jawa Barat: Gratama Publishing, 2014. 
[15] Karim, Adiwarman. 2004. Bank Islam: Analisis Fiqih dan Keuangan. Jakarta: PT. Raja Grafindo.

[16] Perwataatmadja, K., 1997. Syafi'i Antonio. Apa dan Bagaimana Bank Islam. Yogyakarta: PT. Dana Bhakti Wakaf.

[17] Purwanto, Rakhmat dan Widyarti Endang Tri. 2011. Analisis Perbandingan Efisiensi Bank Umum Konvensional (BUK) Dan Bank Umum Syariah (BUS) Di Indonesia Dengan Metode Data Envelopment Analysis (DEA) (Periode 2006-2010).

[18] Rasyid, Abdul. 2016. Spin-Off Unit Usaha Syariah Bank Umum Konvensional. Rubric of Faculty Member. (http://business-law.binus.ac.id/2016/03/28/spin-off-unit-usahasyariah-bank-umum-konvensional/diakses 26 Maret 2018)

[19] Repkova, I., 2014. Efficiency of the Czech Banking Sector Employing the DEA Window Analysis Approach. Procedia Economics and Finance, 12, pp.587-596.

[20] Efficiency of the Slovak commercial banks applying the DEA window analysis. Economics and Management Engineering, 8(5), pp.1320-1325.

[21] Rusydiana, A. S. 2013. Data Envelopment Analysis, CRS dan VRS, (Online), (http: //dea-center.blogspot.co.id, diakses pada 5 Mei 2018).

[22] Muhammad. 2009. Manajemen Bank Syariah. Yogyakarta: UPP STIM YKPN

[23] Muharam, H dan Rizki Pusvitasari. 2007. Analisis Perbandingan Efisiensi Bank Syariah dengan Metode Data Envelopment Analysis (Periode tahun 2005). Jurnal Ekonomi dan Bisnis Islam, Vol.2 No.3.

[24] Muslich, A. and Iswati, S., 2009. Buku Ajar Metodologi Penelitian Kuantitatif. Surabaya: Pusat Penerbitan dan Percetakan UNAIR (AUP).

[25] Nizar, A., 2015. "Analisis Tingkat Efisiensi Bank Umum Syariah Sebelum dan Sesudah Spin Off." Skripsi.

[26] Norfitriani, S., 2017. Analisis Efisiensi Dan Produktivitas Bank Syariah Di Indonesia Sebelum Dan Sesudah Spin Off. JESI (Jurnal Ekonomi Syariah Indonesia), 6(2), pp.134-143.

[27] Otoritas Jasa Keuangan. 2017. Statistik Perbankan Syariah. Jakarta: Otoritas Jasa Keuangan

[28] Permono, Iswardono S. dan Darmawan. 2000. Analisis Efisiensi Industri Perbankan di Indonesia (studi kasus bank-bank devisa di Indonesia tahun 1991-1996. Journal of Indonesian Economy and Business ( JIEB), Vol. 15(1)

[29] Perwataatmadja, K. dan Syafei Antonio. 1997. Apa dan Bagaimana Bank Islam. Yogyakarta: PT Dana Bakhti Wakaf 
[30] Prasetyo Adli,Ghazian. 2016. "Analisis Efisiensi Reksadana Saham Syariah dengan Data Envelopment Analysis metode BCC pada tahun 2002-2015." Skripsi. Universitas Airlangga

[31] Republik Indonesia. Undang-Undang No. 21 Tahun 2008 Tentang Perbankan Syariah.

[32] Sarifudin, M. and Faturohman, T., 2017. Spin-Off Efficiency Analysis of Indonesian Islamic Banks. Journal of Business and Management. Vol. 6, No.2, 2017: 192-202

[33] Shahooth, K. and Battall, A.H., 2006. Using Data Envelopment Analysis to Measure Cost Efficiency with an Application on Islamic Banks. Scientific Journal of Administrative Development, 4(6), pp.134-156.

[34] Sudarsono, Heri. 2004. Bank Lembaga Keuangan Syariah: Deskripsi dan Ilustrasi. Yogyakarta: Ekonisia.

[35] Sugiyono. 2009. Metode Penelitian Kuantitatif, Kualitatif dan R\&D. Bandung: CV Alfabeta

[36] Suseno, Priyonggo. 2008. Analisa Efisiensi dan Skala Ekonomi pada Industri Perbankan Syariah di Indonesia. Journal of Islamic Business and Economics, Vol.2(1), pp: 35-55

[37] Sutawijaya, Adrian dan Etty Puji Lestari. 2009. Analisis Efisiensi dan Skala Ekonomi Pada Industri Perbankan Syariah di Indonesia. Jurnal of Islamic and Economics, Volume 2 No 1 Yogyakarta 